胃全摘術後, 胃切除後の輸入脚の絞扼性イレウスは非常に稀であり, 本邦ではわれわ れの検索しうる限りいまだ報告がみられていない. 今回われわれは, 胃全摘術後 3 年で 発症した輸入脚絞拒性イレウスを経験したので報告する。症例は78歳, 女性. 2002 年に 胃体上部胃癌のため胃全摘, Roux-en Y 再建術を施行されている. 2005年 1 月, 腹痛に て発症し, 当院救急外来受診. 画像検查上, イレウス所見あるものの, 排便も順調であ り, 入院にて経過観察とした. 翌日筋性防御出現, 採血検査で炎症反応，CK の上舁みら れ, CT 検查上, 輸入脚のみの拡張と腹水貯留の所見があり, 同日緊急手術を施行した. Treitz 䩓帯から空腸・空腸吻合部まで腸間膜が約 270 度回転しており，壊死に陥ってい た. 壊死腸管を切除し, Treitz から約 $5 \mathrm{~cm}$ の空腸で, 再度空腸·空腸吻合を行った。 Roux -en $\mathrm{Y}$ 再建後の腹痛の場合，本症例のような病態の存在も考慮すべきである.

卖引用語：輸入脚絞扼性イレウス，急性腹症

\section{緒 言}

胃全摘後・胃切除の輸入脚絞把性イレウスは非常に 稀であり，本邦ではわれわれの検索しうる限りいまだ 報告がみられていない. 今回われわれは胃全摘術後 3 年で発症した輸入脚絞扼性イレウスの1例を経験した のでここに報告する.

$$
\text { 症例 }
$$

患者：78歳，女性.

主訴：腹痛。

既往歴：2002年に胃体上部胃癌のため, 胃全摘術, Roux-en Yによる再建術を施行されている. Stage I A で現在まで再発を認めていない，同年, 急性心筋梗 塞で PTCA 施行されている.また経口摄取不良のため 2002年, 2003 年に 2 回入院している.その際施行され た透視にて吻合部の通過障害は認められていなかつ た。

家族歴・生活歴：特記すへきき事項なし。

現病歴: 平成17年 1 月 23 日夕食後に突然腹痛が出現 し, 次第に増強したため, 同日当院救急外来受診した。 腹部触診で軽度の腹部膨隆と軽度の Blumberg 敒候

2005年 3 月 24 日受付 2005 年 9 月26日採用 〈所属施設住所〉

₹960-0195 福島市鎌田字中江33
を認めた．腹部 $\mathrm{X}$ 線写真上小腸ガスとニボーを認めた ものの, 普通便中等量の排便がみられ, 嘔吐なく, WBC $7,000 / \mu \mathrm{l}, \mathrm{CRP} 0.02 \mathrm{mg} / \mathrm{dl}$, 体温36.7度であり, イレ ウスの診断で入院, 経過観察とした（表 1, 図 1).

入院時現症: 身長 $151 \mathrm{~cm}$, 体重 $40 \mathrm{~kg}$, 体温 $36.7^{\circ} \mathrm{C}$, 血圧, 脈拍, 眼球結膜に黄疸なし. 眼瞼結膜に責血なし.

入院後経過：排便はみられていたもの, 腹痛はさら に增強し, 翌朝には筋性防御が出現. 翌日の採血で, WBC $2,000 / \mu 1, \mathrm{CRP} 4.58 \mathrm{mg} / \mathrm{dl}$ と高度の炎症を思わ せる所見であり, AST, ALT, BUN, Creaの上昇な どがみられ多蔵器不全の徴候がみられた(表 1 )。 また $\mathrm{CK}$ が上昇していることより腸間の絞拓が疑われた。 腹部単純 CT を撮影したところ, 輸入脚と思われる腸 管が高度拡張し，その周囲に腹水が貯留している所見 があり(図 2 ), 輸入脚部絞扼性イレウスの疑い, 汎発 性腹膜炎の診断で同日緊急手術を施行した。

手術所見：中腹部正中切開で開腹した. 血性で軽度 腐敗臭のある腹水を中等量認めた。Treitz 靶带から空 腸一空腸吻合部までの輸入脚が図 3 のごとく回転して おり, 絞抳されていた(図 4). 絞扼を解除したが, 腸 管の色調は戻らなかったため, Treitz 勒帯より約 5 $\mathrm{cm}$ の空腸から, 空腸一空腸吻合部までの腸間約 $15 \mathrm{~cm}$ を切除し, 新たな空腸一空腸吻合を行い, 再建した。

術後経過：手術翌日よりMOF となり，人工呼吸下 
表 1 入院時 $(1 / 23)$ ，入院後 $(1 / 24)$ 血液検查

\begin{tabular}{|c|c|c|c|c|c|}
\hline & 1月23日 & 1月24日 & & 1月23日 & 1月24日 \\
\hline $\operatorname{WBC}(/ \mu 1)$ & 7000 & $\underline{2.000}$ & $\mathrm{TP}(\mathrm{g} / \mathrm{dl})$ & 7.2 & 5.3 \\
\hline $\operatorname{RBC}(/ \mu 1)$ & $3.84 \times 10^{6}$ & $3.95 \times 10^{6}$ & $\operatorname{AST}(\mathrm{IU} / 1)$ & 32 & 106 \\
\hline $\mathrm{Hb}(\mathrm{g} / \mathrm{dl})$ & 12.2 & 12.1 & $\operatorname{ALT}(\mathrm{IU} / \mathrm{l})$ & 22 & 62 \\
\hline $\mathrm{Ht}(\%)$ & 35.6 & 37.3 & $\mathrm{LDH}(\mathrm{IU} / \mathrm{l})$ & $\underline{246}$ & $\underline{447}$ \\
\hline \multirow[t]{2}{*}{$\operatorname{PLT}(/ \mu 1)$} & $198 \times 10^{3}$ & $209 \times 10^{3}$ & $\operatorname{ALP}(I U / 1)$ & 294 & 189 \\
\hline & & & $\mathrm{TB}(\mathrm{mg} / \mathrm{dl})$ & 0.67 & $\underline{1.71}$ \\
\hline $\mathrm{pH}$ & & 7.361 & $\operatorname{BUN}(\mathrm{mg} / \mathrm{dl})$ & 19.6 & $\underline{30.9}$ \\
\hline $\mathrm{pO}_{2}(\mathrm{mmHg})$ & & 100.1 & Crea (mg/dl) & 0.45 & $\underline{1.49}$ \\
\hline $\mathrm{PCO}_{2}(\mathrm{mmHg})$ & & $\underline{31.9}$ & $\mathrm{CK}(\mathrm{IU} / 1)$ & 146 & $\underline{1420}$ \\
\hline $\mathrm{HCO}_{3}(\mathrm{mmol} / 1)$ & & $\underline{17.7}$ & $\mathrm{Na}(\mathrm{mEq} / \mathrm{l})$ & 142 & 137 \\
\hline \multirow[t]{5}{*}{$\mathrm{BE}(\mathrm{mmol} / \mathrm{l})$} & & $\overline{-7.8}$ & $\mathrm{~K}(\mathrm{mEq} / \mathrm{l})$ & 4.7 & 4.7 \\
\hline & & & $\mathrm{Cl}(\mathrm{mEq} / \mathrm{l})$ & 105 & 101 \\
\hline & & & AMY (IU/1) & 96 & $\underline{388}$ \\
\hline & & & $\mathrm{CRP}(\mathrm{mg} / \mathrm{dl})$ & 0.02 & $\underline{4.58}$ \\
\hline & & & $\mathrm{BS}(\mathrm{mg} / \mathrm{dl})$ & 175 & $\underline{212}$ \\
\hline
\end{tabular}

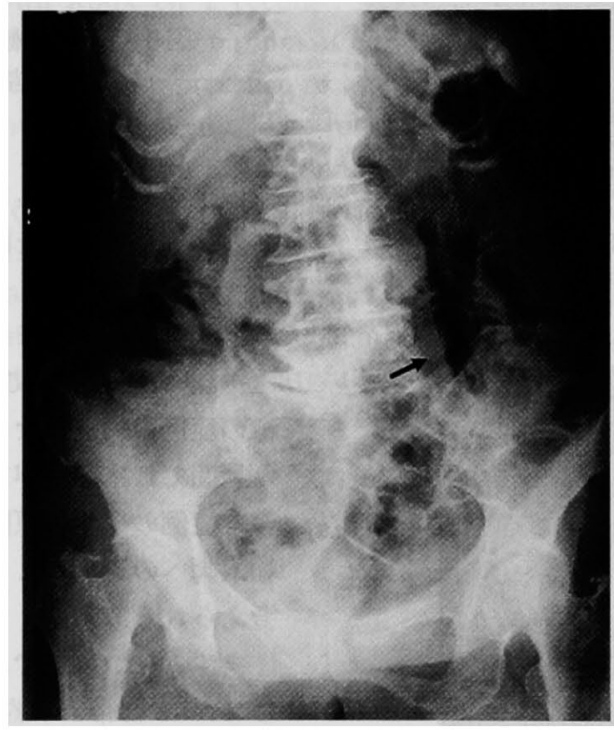

図 1 腹部 X 線検査：左上腹部に限局して小腸 の拡張, 小腸ガスが見られる (矢印).

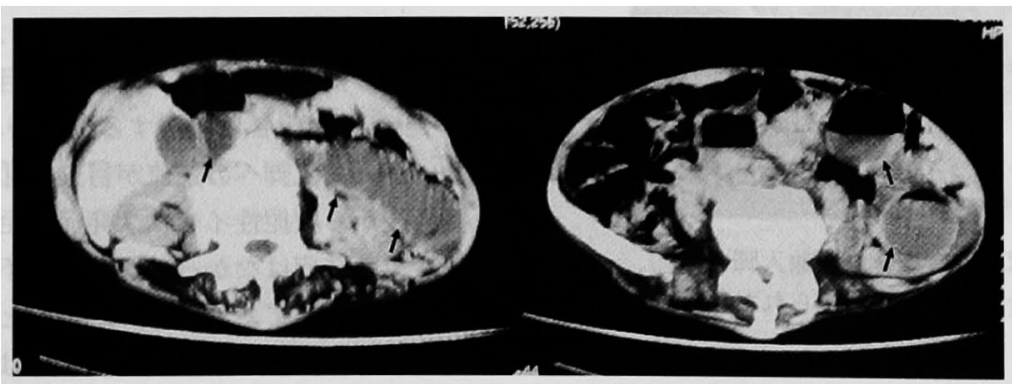

図 2 脈部単純 CT 検査 : 輸入脚の拡張 (矢印) と,その周囲に腹水の貯留が認め られる。 


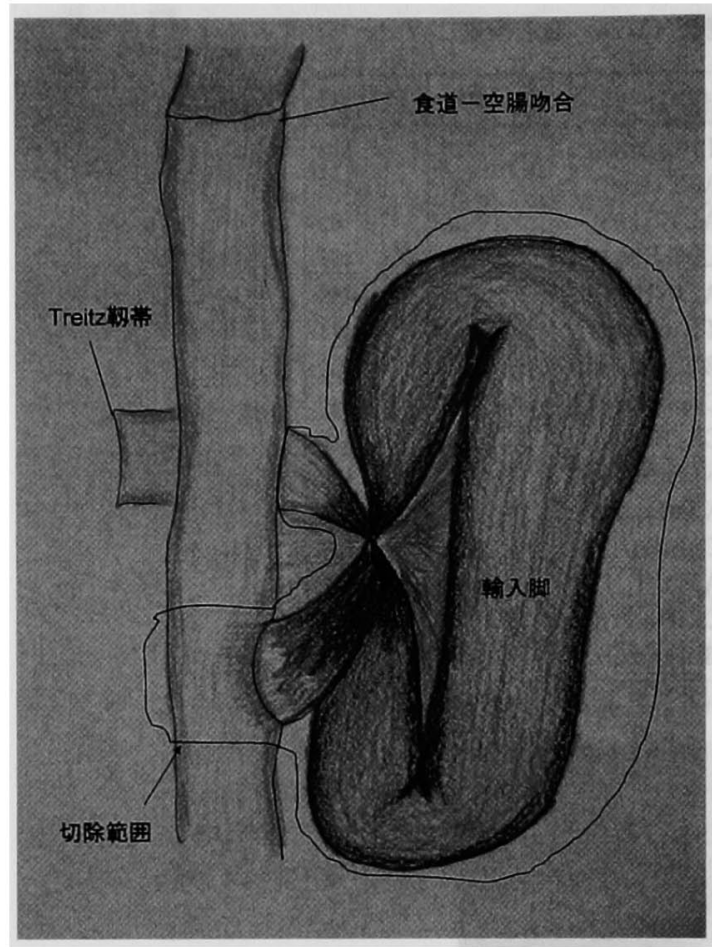

図 3 絞扼部の模式図: Treitz 靶帯から約 $5 \mathrm{~cm}$ 空腸 一空腸吻合部までが絞拒され，壊死に宿っていた。

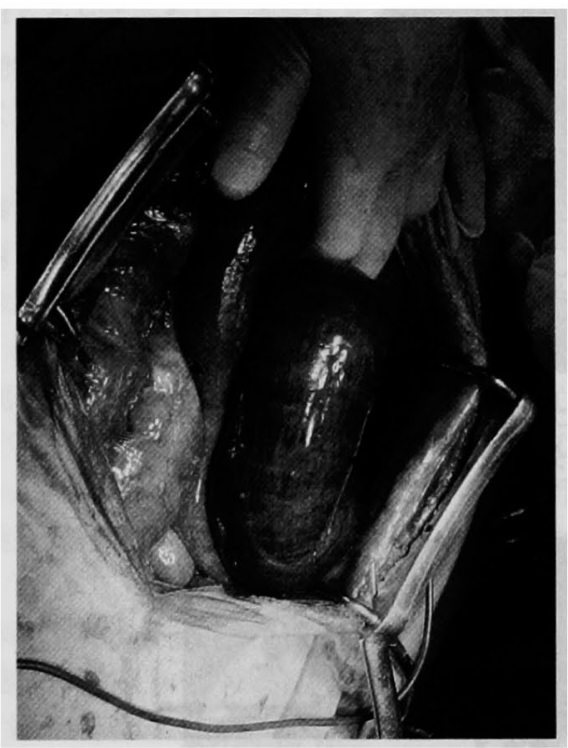

図 4 術中写真：絞扼された輸入脚 (矢印). その隣は食道へと吊り上げられた空腸（矢 頭).

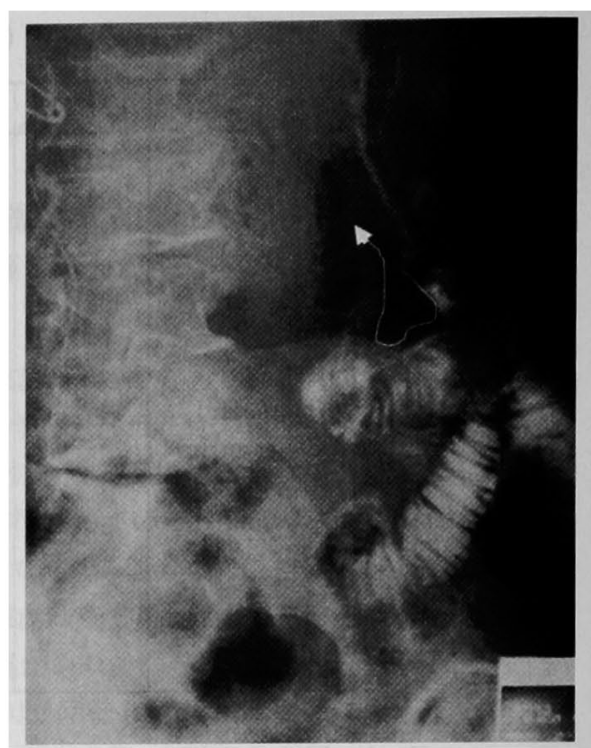

图 5 胃全摘術後消化管造影写真：輸入 脚 への比較的容易な逆流あり。

での集中治療を要したが，次第に状態は改善し，術後 3 週目で経口捸取を開始した。

$$
\text { 考察 }
$$

輸入脚の絞抑性イレウスは非常に稀な疾患である。 医中誌 web を用いて検索したところ，1983年以降，同 様の症例の報告はなされておらず，われわれが調べ得 た範囲では本症例が本邦ではじめての報告である。

本症例の発症の原因については，(1)輸入脚の過長(2) 輸入脚への逆流による輸入脚拡張（輸入脚症候群）が 考えられる.

まず(1)についてであるが，われわれは輸入脚の長さ は Treitz 靯帯より約 $15 \mathrm{~cm}$ としており，一般的な外科 手術の手引き書に準じている ${ }^{1) 2}$. 本症例についても同 様であり，多少長くなってしまったことは考えられる が,大きくずれていることはない.したがって本症例に ついては $15 \mathrm{~cm} て ゙ は$ 結果的に長かった可能性がある。

(2)についてであるが, 術後 6 日目の術後透視の画像 を retrospectiveに検討すると，特異的所見とはいえ ないが，輸入脚への逆流が目立つ(図 5 )。患者は胃全 摘術後から絞把性イレウス発症に至るまで明らかなイ レウスの発症はなかったが，食欲不振や嘔吐を強く訴 え 2 回入院しており，これが原因となっていたことも 考えられる。なお本症例に関しては，胃全摘術時に， 輸入脚の吊り上げを数針行い，腸間膜は縫合固定して いる。 
結 語

本邦で初と思われる胃全摘術後の輸入脚の絞㧪性イ

レウスを経験したので報告した. Roux-en Y 再建を行 った患者で強い腹痛を訴えた場合は，本症を考える必 要がある。

\section{文献}

1）鍋谷圭宏, 落合武徳：胃全摘後再建術. 手術 58 ： $853-860,2004$

2）枚野尚彦，篠原 尚：イラストレイテッド外科手 術. 第 2 版, 医学書院, 東京, 1997, p55-93

\title{
A CASE OF STRANGULATING ILEUS OF THE AFFERENT LOOP AFTER TOTAL GASTRECTOMY
}

\author{
Wataru SAKAMOTO, Yoshiro ANDO, Naoki SATO and Seiichi TAKENOSHITA* \\ Department of Surgery, Ohara Medical Center \\ *Second Department of Surgery, Fukushima Medical University
}

Strangulatign ileus of the afferent loop after gastric resection is a very rare complication. There is no such such report in Japan up to now as far as we could search in the literatures. This is the report of a case of such complication 3 years after total gastrectomy. The patient was a 78-year-old female, who had total gastrectomy with Roux-en Y reconstruction in 2002 for cancer of the upper portion of stomach. The patient came to the emergency room of our hospital with the complaint of abdominal pain in Jan. 2002. X-ray studies revealed the presence of an ileus, however the patient was observed in the hospital as she had normal bowel movements. The following day of admission she developed muscular gurding of the abdomen with positive sign of inflammation in the blood test and showed a rise of CK enzyme. CT study revealed dilatation of the afferent loop with fluid accumulation. Accordingly an emergent laparotomy was performed on the same day. The mesenterium between Treitz ligament and jejuno-jejunal anastomosis was rotated 270 degrees and the bowel was necrotic. The necrotic jejunum was resected and a new anastomosis was made at $5 \mathrm{~cm}$ below Treitz ligament. Abdominal pain that appears after Roux-en $\mathrm{Y}$ anastomosis should be carefully evaluated with the above complication in mind. 